\title{
TRADE-BASED MONEY LAUNDERING: RESPONDING TO AN EMERGING THREAT
}

\section{SAMUEL MCSKIMMING*}

Concerted global effort has made the financial system an increasingly hostile and risky environment in which to launder illicit funds. As a result, offenders are increasingly turning to money laundering typologies that operate outside the financial system - primarily, trade-based money laundering. Despite this, enforcement agencies are ill-equipped to systematically detect and prevent trade-based financial crime. This paper makes several observations. The first is that, while little has been done to prevent trade-based financial crime, there is also little evidence of its ill effect. Further, there has been little consideration as to whether systematic monitoring of the trade system would be cost-effective, relative to the number of offenders detected and the harm prevented. Without such analysis, it is almost impossible to reach a measured and balanced view on appropriate policy settings. The second is that, even if monitoring were to be implemented, the analytical methodologies that are currently used have major flaws. They not only rely on data that is often of poor quality, but may also be worryingly easy to circumvent. This too raises serious questions about the effectiveness of the proposed policy responses to tradebased money laundering. The difficulties associated with data monitoring also raise the spectre of a significant increase in the number of physical, and therefore costly, inspections of trade goods.

\section{INTRODUCTION}

The front door of money laundering is the banking system ... the government has done a pretty good job of closing the front door, but the back door - international trade - is wide open.

John Zdanowicz ${ }^{1}$

\footnotetext{
* Researcher to the Hon JJ Spigelman AC, Chief Justice of New South Wales.

The author acknowledges the helpful comments of Jim Joliffe, Deputy Director of Public Prosecutions (Cth), on an earlier version of this paper.

${ }^{1}$ Quoted in 'Trade-based money laundering flourishing', United Press International (online), 11 May $2009<$ <ttp://www.upi.com/Top_News/2009/05/11/Trade-based-money launderingflourishing/UPI-17331242061466/>.
} 
In 1995, a consignment of mink furs was shipped to the United States from Greece. At a mere US\$12.31 each, the furs cost the importer about one per cent of what they were actually worth. ${ }^{2}$ That same year, a Greek importer purchased electrical capacitors from the US at US\$1 560 each - a mark-up of 30316 times the normal price. ${ }^{3}$ Thousands upon thousands of commercially suspect international trade transactions like these occur every year. ${ }^{4}$ The literature is replete with examples: an $\$ 82$ set of golf clubs imported for \$4 976, a \$25 hairdryer imported for \$3 800 and a \$63 generator imported for a staggering $\$ 60000 .^{5}$ Suspicious transactions such as these might indicate the existence of any number of different financial crimes, including customs fraud, capital flight, quota avoidance, smuggling, or money laundering. ${ }^{6}$ However, somewhat anomalously given the global importance attached to anti-money laundering and counter-terrorist financing ('AML/CTF') efforts, systematic and comprehensive monitoring of trade transactions is almost nonexistent. $^{7}$

Law enforcement is only now beginning to contemplate the challenge that trade-based money laundering and terrorist financing ('TBML/TF') presents. Comprehensive and expansive regulation of the financial system has made the banking system transparent and therefore increased the risk of detection for those seeking to launder illicit funds through it. ${ }^{9}$ As a result, offenders are reportedly turning to the comparatively unregulated global trade system as an

\footnotetext{
2 Simon J Pak, Stelios H Zanakis and John S Zdanowicz, 'Detecting Abnormal Pricing in International Trade: The Greece-USA Case’ (2003) 33(2) Interfaces 54, 57.

${ }^{3}$ Ibid.

${ }^{4}$ Maria E de Boyrie, Simon J Pak and John S Zdanowicz, 'Money Laundering and Income Tax Evasion: The Determination of Optimal Audits and Inspections to Detect Abnormal Prices in International Trade' (2004) 12(2) Journal of Financial Crime 123, 123 ('Money Laundering and Income Tax Evasion').

${ }^{5}$ Maria E de Boyrie, James A Nelson and Simon J Pak, 'Capital Movement through Trade Misinvoicing: The Case of Africa' (2007) 14(4) Journal of Financial Crime 474, 474 ('Capital Movement through Trade Misinvoicing').

${ }^{6}$ Ibid 475.

${ }^{7}$ Ross S Delston and Stephen C Walls, 'Reaching Beyond Banks: How to Target Trade-Based Money Laundering and Terrorist Financing outside the Financial Sector' (2009) 41(1) Case Western Reserve Journal of International Law 85, 99.

${ }^{8}$ Financial Action Task Force, Trade Based Money Laundering (Report, Organisation for Economic Co-operation and Development, 23 June 2006) 1 ('Trade Based Money Laundering').

${ }^{9}$ For example, Marie de Boyrie et al have found that the application of strict AML/CTF laws to the Swiss financial sector was positively correlated with an increase in abnormal trade pricing. See Marie E de Boyrie, Simon J Pak and John S Zdanowicz, 'The Impact of Switzerland's Money Laundering Law on Capital Flows Through Abnormal Pricing in International Trade' (Working Paper, Center for International Business and Education Research, Florida International University, April, 2001), 16-17 ('The Impact of Switzerland's Money Laundering Law').
} 
alternative mechanism for laundering funds internationally. ${ }^{10}$ From an enforcement perspective, the prospect of offenders switching from the financial sector to the trade sector implies a broad and complex substitution effect between the two. It does not, however, imply, for the reasons given below, that TBML/TF is 'just another typology'. Instead, TBML/TF is better conceptualised as one of three broad 'classes' of offences.

Under this classification, used by the Financial Action Task Force ('FATF'), amongst others, money laundering occurs either: (i) through the financial system; (ii) through the physical movement of currency; or (iii) through the movement of goods. ${ }^{11}$ While, of course, any single offence might use methods from more than one category, the taxonomy highlights three important points. First, mechanisms designed to detect and prevent one such class will not necessarily be effective against others. ${ }^{12}$ Secondly, increased detection in one class will encourage illicit activity to shift to another. ${ }^{13}$ With regard to the latter point, substitution between the three classes of offence implies that an aggressive response to the first two classes (for example the Anti-Money Laundering and Counter-Terrorism Financing Act 2006 (Cth)) may, ultimately, do little to reduce the overall volume of money laundering. Lastly, it serves to highlight the fact that, at least with respect to offenders switching to $\mathrm{TBML} / \mathrm{TF}$, moving between classes is not as simple as alternating between the various financial sector typologies.

As noted above, the classification highlights the fact that an increase in law enforcement resources dedicated to financial sector offences will not necessarily cause a concomitant decrease in trade-based crime. Tweaks to the existing regulatory apparatus - focused as it is on financial sector risk assessment, transactional observation and centralised reporting of homogeneous data points - will not detect offences occurring in the trade system. Financial transaction reporting - the 'backbone of most countries' AML/CTF regimes, ${ }^{14}$ - is fundamentally incapable of detecting most tradebased financial crime. Instead, there is a broad recognition amongst officials that new surveillance and investigative tools will be required to deal with a very different sector of the economy. ${ }^{15}$ This implies further regulation and,

\footnotetext{
${ }^{10}$ Ibid; Delston and Walls, above n 7, 86-7.

${ }^{11}$ Trade Based Money Laundering, above n 8, 1.

${ }^{12}$ Delston and Walls, above n 7, 86-8.

${ }^{13}$ De Boyrie, Pak and Zdanowicz, The Impact of Switzerland's Money Laundering Law, above n 9, 16-17; Trade Based Money Laundering, above n 8, 1.

${ }^{14}$ Bureau for International Narcotics and Law Enforcement Affairs, United States Department of State, International Narcotics Control Strategy Report: Vol II - Money laundering and Financial Crimes (2009) 5 ('International Narcotics Control').

${ }^{15}$ Ibid.
} 
therefore, further cost. Indeed, in this latter respect, it is evident that a monitoring regime for the trade system will not only have to supervise staggering trade volumes, but also a freight transport industry that is opaque in nearly every respect. The challenges are immense.

First, the size of international trade, measured in both volume and value, is unfathomably large. In 2007, the value of international trade transactions was around US\$25 trillion, up from around US\$17 trillion in $2004 .^{16}$ Of this, estimates of the amount laundered range into the 'hundreds of billions', ${ }^{17}$ with the amount tainted by capital flight or tax minimisation likely to be many times higher still.

In volume terms, in 2006, there were 440 million movements of twenty-foot container equivalents in and out of the world's maritime ports. ${ }^{18}$ This equates to billions of cubic feet of 'shipping space' that might require physical inspection. Indeed, around seven and a half billion tonnes of materials were shipped by maritime transport alone in $2006,{ }^{19}$ a number that excludes landbased trade and air-freight. Given that physical inspection is required to detect many TBML/TF typologies, the logistical challenge posed by such volumes is self-evident and overwhelming. Unsurprisingly, inspection rates are very low; most countries inspect less than five per cent of incoming trade. ${ }^{20}$ In Australia, for example, in 2006-7, around 140000 TEUs $^{21}$ were x-rayed and 15000 physically inspected ${ }^{22}$ - against a total TEU throughput of around 5.3 million. ${ }^{23}$ In this context, detecting and prosecuting TBML/TF is much like finding a needle in a pile of other needles.

\footnotetext{
${ }^{16}$ John W Miller, 'Global Trade Talks Fail as New Giants Flex Muscle' Wall Street Journal (online), 30 July 2008 <http://online.wsj.com/article/SB121734618198593583.html? mod=hps_us_whats_news $>$.

${ }^{17}$ International Narcotics Control, above n 14, 5.

${ }^{18}$ United Nations Conference on Trade and Development, Review of Maritime Transport, UN Doc CTAD/RMT/2007 (7 December 2007) 87.

${ }^{19}$ Ibid 4.

${ }^{20}$ Delston and Wall, above n 7, 87; Trade Based Money Laundering, above n 8, 2.

${ }^{21}$ One TEU is generally defined as equivalent to a standard intermodal-shipping container. However, TEU height is not standardised - the most common height is 2.6 metres, which equates to a shipping volume of 1360 cubic feet per container.

${ }^{22}$ Australian Customs Service, 'Annual Report 2007-08' ('Annual Report, 2008'), 38.

${ }^{23}$ Australia has five container handling ports. The individual throughputs for 2006-7 are as follows: Adelaide (219 000 TEUs); Fremantle (506 000 TEUs); Brisbane (875 000 TEUs); Sydney Ports (1 620000 TEUs); Melbourne Ports (2 093000 TEUs). See Bureau of Infrastructure, Transport and Regional Economics, Australian Container Ports in an International Context (Information Paper No. 65, BITRE, September 2009) 21.
} 
Second, the opaque nature of the international trade sector makes reliable and cost effective monitoring by law enforcement bodies extremely difficult. There are a number of reasons for this. Most fundamentally, because anything moveable is a potential store of value, monitoring capital movements in the trade system involves complex surveillance of an impossibly large number of different commodities. Secondly, every jurisdiction imposes its own regulatory requirements on the type and quantity of documentary evidence accompanying trade shipments. There is enormous variation in the substance of these requirements. Misleading, incomplete, inaccurate or even illegible records are routinely provided to government agencies. ${ }^{24}$ Many transactions are still conducted using paper records, often handwritten, in multiple languages, with even the simplest transaction often requiring more than twenty separate records. ${ }^{25}$ The United Nations Conference on Trade and Development ('UNCTAD') has described trade paperwork in the following terms:

National and international businesses, traders and transport operators are faced with numerous documents and forms (up to 40 originals), often containing redundant and repetitive data and information (200 data elements on average). These documents, frequently not standardized, are complex and cumbersome for traders to complete and for authorities to verify. Moreover, if they exist only in one language, such documents and forms might be difficult to understand. Excessive paperwork takes more time for import/export and transit procedures and formalities and calls for the employment of more human resources in government and the private sector. This invites errors in submissions and malfeasance, raises trade transactions costs, and slows down trade flows. ${ }^{26}$

Finally, the various 'layers' involved in any one transaction do not aid transparency and can in fact work against it. Nominee shipping, in particular, is extremely common, as is the use of retail freight forwarders ${ }^{27}$ that process and consolidate goods from hundreds of consignors. Illicit and legitimate funds might be commingled by these nominees or forwarders, as indeed might

${ }^{24}$ Nikos Passas, 'Setting Global CFT Standards: A Critique and Suggestions' (2006) 9(3) Journal of Money Laundering Control 281, 286; Nikos Passas and Kimberly Jones, 'The Regulation of Non-Vessel-Operating Common Carriers (NVOCC) and Customs Brokers: Loopholes Big Enough to Fit Container Ships' (2007) 14(1) Journal of Financial Crime 84, 85.

${ }^{25}$ Åke Nilson, 'Electronic Bills of Lading — Planning for Areas of Risk’ (1995) 2(4) Journal of Financial Crime 311, 311.

26 UNCTAD Trust Fund for Trade Facilitation Negotiations, Simplification of Trade Documentation Using International Standards, UN Doc TN/TF/13 (26 March 2006) 1 ('Simplification of Trade Documentation').

27 A freight forwarder retails intermodal carrier services, as well as providing customs clearance, brokerage, insurance, documentation, export packing, etc. 
be both illicit and legitimate goods over which they have a bailment. Socalled 'groupage shipments, ${ }^{28}$ may contain thousands of distinct products, many of which are sparsely or inaccurately described by the consignor. Bills of lading and other tradeable instruments, such as documents of title, ${ }^{29}$ disassociate ownership and possession, obscuring the shipping parties still further. Given this, a standardised approach to intelligence-gathering in the trade sector, especially in light of the data-quality and -consistency issues that have arisen over the last two decades in the much simpler financial sector, presents tremendous challenges.

This paper is structured as follows. In Part II, it outlines the two major TBML/TF typologies: abnormal pricing and falsely described goods or services. In Part III, the paper highlights the challenges posed by TBML/TF for law enforcement and the inadequacy of the investigative tools so far conceived. Finally, in Part IV, this paper discusses the economic and social implications of TBML/TF. Part V concludes.

\section{THE MAJOR TBML/TF TYPOLOGIES}

At the broadest level of abstraction, the purpose of international trade fraud is to transfer value between jurisdictions and/or avoid tax obligations. In the case of money laundering, there is an additional motivation: to conceal the origin of illegally obtained capital by creating the impression that it was derived from an ostensibly legitimate transaction. Conversely, in the case of terrorist financing, the fraud is motivated by the need to conceal the destination of the capital by legitimising the beneficiary. In both cases, though TBML/TF has only recently come to the attention of law enforcement officials, the typologies used by offenders are often much older. In particular, capital movements in the trade system have long been associated with tax evasion and the avoidance of capital export rules. ${ }^{30}$

\footnotetext{
${ }^{28}$ Groupage shipments are those where shipments from multiple parties are consolidated into a single shipping crate. Often, groupage crates are shipped by companies who take goods on consignment from multiple freight forwarders, who themselves have accepted goods on consignment from the actual shipper.

${ }^{29} \mathrm{~A}$ bill of lading is a contract for carriage between the shipper and the carrier. However, it is also a document of title that can be endorsed in a similar way to a cheque. This allows a buyer of goods to enforce the conditions of carriage against the carrier, thereby circumventing privity of contract and allowing sale of goods in transit.

${ }^{30}$ Trade Based Money Laundering, above n 8, 2.
} 
In this section of the paper, TBML/TF typologies are crudely divided in two price and volume based methods, each considered below. While this taxonomy is convenient, actual offences are likely to use a mixture of each method, as well as using traditional financial system typologies. ${ }^{31}$ Further, in both cases, there are two preconditions for TBML/TF to be effective. The first precondition is that collusion between the parties is ordinarily required for TBML/TF typologies to have a capital transfer function. ${ }^{32}$ The second precondition is that the amount laundered has to exceed any trade transaction costs for which the syndicate is liable (for example, shipping costs, insurance, tax, transport risks and shipping time). These costs are non-trivial, which may mean that larger syndicates are the primary users of TBML/TF.

\section{A Abnormal Pricing of Trade-Goods and Services}

Abnormal trade pricing occurs when the import or export price for a particular good is invoiced at a level that either exceeds the market price (overinvoicing) or is below the market price (under-invoicing). Because of its obvious role in duties- and tariff-fraud, abnormal pricing is a primary focus of customs authorities. However, abnormal pricing is also one of the oldest and best known ways of transferring capital across borders. ${ }^{33}$ As discussed later in this paper, abnormal trade pricing is often observed in countries at risk of capital flight, for example those subject to political or economic turbulence, and/or those with tight foreign currency restrictions. More recently, attention has been devoted to the use of abnormal trade pricing for money laundering purposes. $^{34}$

As noted above, the mispricing of trade goods has a central role in tax evasion. For example, Simon Pak and John Zdanowicz estimate that the US Treasury lost US\$35.6 billion and US\$46.2 billion in tax revenues in 1998 and 1999 respectively, due to abnormal trade pricing. ${ }^{35}$ This tax fraud occurs in two primary ways. The first, simply, is the abnormal pricing of trade goods

\footnotetext{
${ }^{31}$ Ibid 7.

32 Ibid 5.

33 De Boyrie, Pak and Zdanowicz, The Impact of Switzerland's Money Laundering Law, above n 9, 5-7.

34 Trade Based Money Laundering, above n 8, 2.

35 Simon Pak and John Zdanowicz 'Executive Summary: US Trade with the World - An Estimate of 1998 Lost U.S. Federal Income Tax Revenues Due to Over-Invoiced Imports and Under-Invoiced Exports' (Trade Research Institute, Report 9904-01, 1999) cited in De Boyrie, Pak and Zdanowicz, The Impact of Switzerland's Money Laundering Law, above n 9, 4.
} 
to reduce import duties (underpricing of invoices) or to inflate export subsidies (overpricing of invoices). The second, more recent, phenomenon is transfer pricing. This is where an entity conducting economic activity in two countries uses internal 'transfer' prices to shift taxable income from countries of high taxation to countries of low taxation. Because transfer pricing is conducted under the auspices of a single entity, central revenue authorities, rather than border authorities, normally address it. This paper does not consider transfer pricing. However, as both under-invoicing and overinvoicing are also major TBML/TF typologies, there are good reasons to think that TBML/TF compliance will resemble trade tariff regulation. Indeed, given that TBML/TF typologies almost always amount to customs fraud, the potential synergies between border revenue authorities and organised crime law enforcement are highly relevant.

In the TBML/TF context, under-invoicing transfers value from the exporter to the importer. The exporter sells goods to the importer for a below-market, discounted price. On receipt of the goods, the importer resells them and pockets the difference between the invoiced price and the sale price. The exporter has successfully transferred value overseas, with both parties being able to point to an ostensibly legitimate trade to justify the transaction. The importer, in particular, is able to explain the receipt of illicit funds by an actual market transaction with an unrelated third party. It must be noted that, as the exporter had to acquire the goods in the first place for a market price and as the second sale proceeds on a cost recovery basis, the syndicate does not make a 'profit'. Conceivably, a small profit might result from price discrepancies between countries - but it seems more likely that a small loss would result because, in all probability, TBML/TF syndicates buy and sell trade goods indiscriminately and without commercial acumen. A particular advantage of under-invoicing is that each party benefits from reduced taxation and, therefore, lower transaction costs. Lower revenue for the exporter will minimise its taxable income (or even give it a tax loss) whereas the importer will reduce the import tariffs (if any) levied on the goods ${ }^{36}$ (although it may be liable for income tax on abnormal profits). This typology is illustrated diagrammatically in Figure 1 below.

\footnotetext{
${ }^{36}$ Pak, Zanakis and Zdanowicz, above n 2, 54.
} 
Figure 1: Under-invoicing of trade-goods

Pays income tax

on $\$ 2000$

not $\$ 5000$

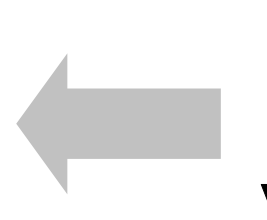

1. Sells 1000 widgets at $\$ 2$ each

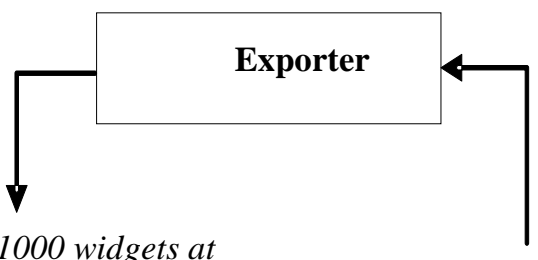

2. Remits $\$ 2000$

Pays import duties on $\$ 2000$ only but does not have to pay income tax on abnormal profit of $\$ 3000$

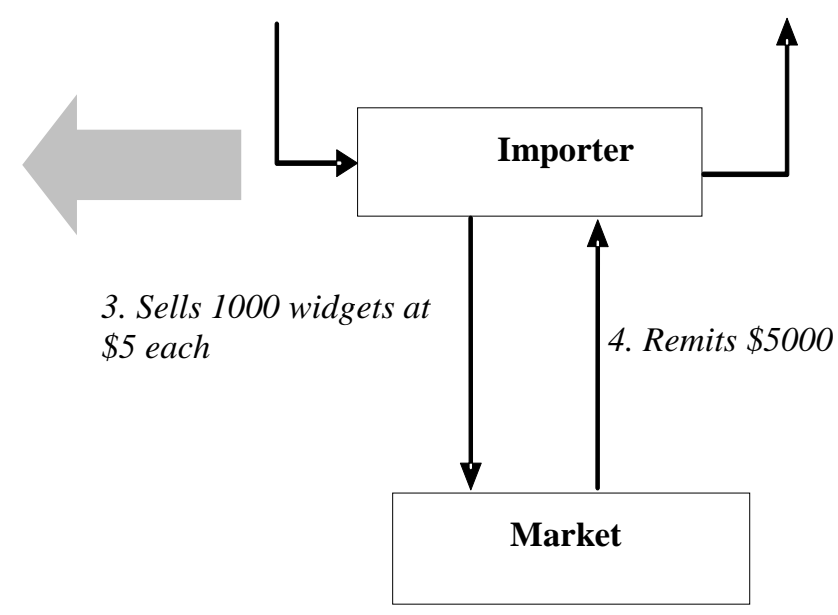

Over-invoicing transfers value from the importer to the exporter. The exporter, by setting an abnormally high price, receives a better price for goods than it could achieve on the open market. The importer then resells the goods, recouping the cost of acquiring the goods in the first place for the syndicate. In circumstances where the over-invoicing is extreme, for example in the case of the $\$ 1500$ capacitor mentioned earlier, this resale may not occur, as the cost to the syndicate of acquiring the goods is trivial. ${ }^{37}$ In an over-invoiced transaction, the amount transferred is the difference between the market price in the import country and the invoice price. The taxation implications of the transaction are generally undesirable as the importing firm will pay higher duties and the exporting firm will pay higher income taxes. One benefit, however, is that the importing firm will increase its cost base and pay lower income taxes as a result, ${ }^{38}$ and the exporting firm may be able to fraudulently

\footnotetext{
${ }^{37}$ In such circumstances, as the goods are largely worthless, one might argue that this is, in effect, a phantom shipment (where no goods are transferred).

${ }^{38}$ Pak, Zanakis and Zdanowicz above n 2, 54.
} 
claim an export tax credit. ${ }^{39}$ This typology is illustrated diagrammatically in Figure 2 below.

\section{Figure 2: Over-invoicing of trade-goods}

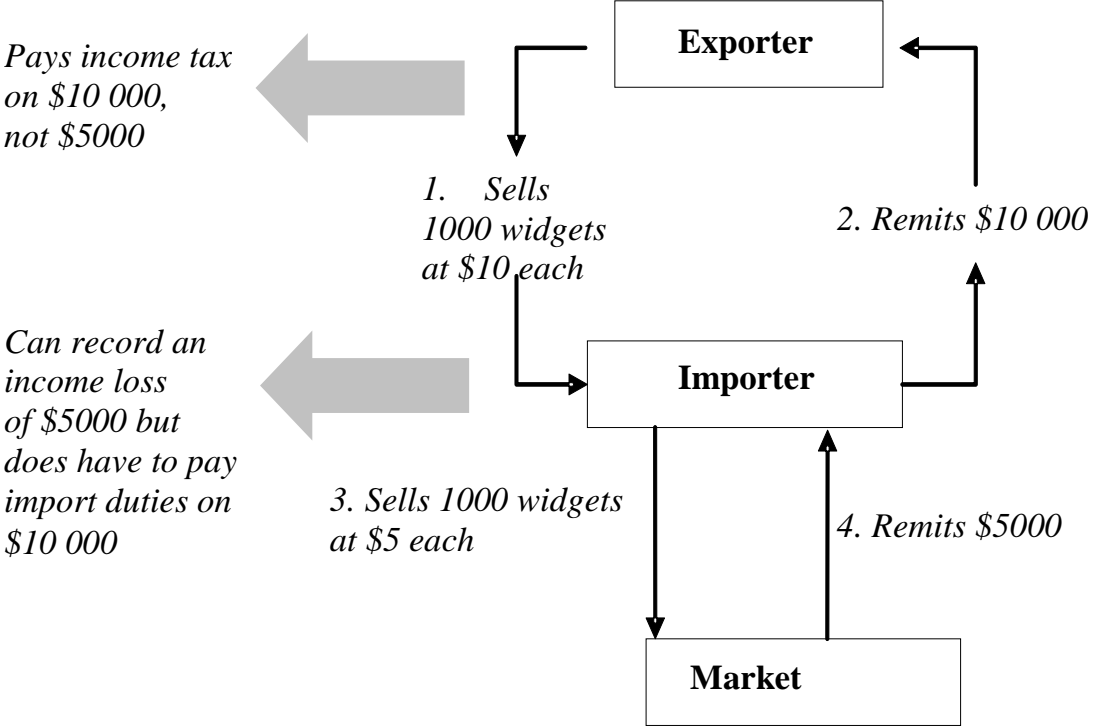

In either typology, there is arguably a preference amongst money launderers for: high-value but easily transportable items (for example jewellery); ${ }^{40}$ goods that do not attract import/export duties and hence generate little attention from customs; ${ }^{41}$ goods that are easily traded on secondary markets (for example commodities or precious minerals) $;^{42}$ non-perishable goods; or heterogeneous goods that are difficult for customs to value (for example art or antiques). ${ }^{43}$

It is important to note that while the terminology of over- and under-invoicing implies that the invoice itself is defective, the headline price on the actual commercial invoice need not be misrepresented for the transaction price itself

\footnotetext{
${ }^{39}$ Trade Based Money Laundering, above n 8, 5; Konstantin V Pashev 'Countering CrossBorder VAT Fraud: The Bulgarian Experience’ (2007) 14(4) Journal of Financial Crime 490, 491.

${ }^{40}$ Money Laundering Threat Assessment Working Group, U.S. Money Laundering Threat Assessment (Working Paper, United States Department of Treasury, December 2005) 44 ('U.S. Money Laundering Threat Assessment').

${ }^{41}$ Trade Based Money Laundering, above n 8, 5.

${ }^{42}$ U.S. Money Laundering Threat Assessment, above n 40, 43.

${ }^{43}$ Trade Based Money Laundering, above n 8, 5.
} 
to be abnormal. Common variations to the above typologies involve adjusting the transaction price (that is, the amount transferred between the parties) in plausible but indirect ways. These variations often involve an accurate valuation in the top line price for trade goods (thus minimising the chance of a customs inspection) supplemented by a convincing explanation for why the amount paid or received differs from the invoice. For example, this might involve issuing two invoices for a single shipment, issuing an amending invoice, charging late or administrative fees, or providing 'credits' for nonexistent refunds and returns. ${ }^{44}$ Where these methods are used, detecting abnormal pricing can require an audit of the transaction in its entirety.

While the above discussion concerns trade in goods, it is possible that abnormal pricing could be used with respect to trade in services. ${ }^{45}$ However, services, by their nature, are not usually transferable to third parties. This illiquidity makes trade in services unsuited to a typology that requires resale, such as under-invoicing. Services are more likely to be over-invoiced: the exporter will receive greater value than the service rendered without then having to complete a second transaction to make that value fungible. This would include circumstances where no services are provided at all. In fact, given the nature of the offence, it seems unlikely that actual, valuable and legitimate services would ever be rendered in a TBML/TF transaction. There is a question about whether the absence of transaction costs makes trade in services more likely (in that it is less costly) or less likely (in that less explanatory paperwork is generated, and thus, the deception is less comprehensive).

Of the two typologies discussed above, under-invoicing is preferred by money launderers for two reasons. First, under-invoicing does not involve any contact with the financial system at the vulnerable placement stage. ${ }^{46}$ To under-invoice, an offender can purchase any tradeable good using cash or other unwashed monies - presumably from a vendor that has no obligation or reason to suspect the legitimacy of the transaction. By the time a reportable financial transaction occurs, that is, when the revenue is banked, the money is already cloaked by an ostensibly legitimate trade transaction. In contrast, to launder money through over-invoicing, criminal proceeds must first be placed with a financial institution to pay the inflated invoice, for example, because a foreign exchange is required and the counterparty is located abroad. This creates a reportable (and suspicious) transaction prior to the trade occurring.

\footnotetext{
${ }^{44}$ Ibid.

${ }^{45}$ Ibid.

${ }^{46}$ De Boyrie, Pak and Zdanowicz, The Impact of Switzerland's Money Laundering Law, above n $9,8$.
} 
Second, in the case of over-invoicing, it is the importer that seeks to shift capital overseas, whereas in the case of under-invoicing it is the exporter. Importers are rigorously scrutinised by regulatory authorities as they are liable for import duties and have a general quarantine/security function. This scrutiny discourages money launderers. ${ }^{47}$ That said, because under-invoicing is simultaneously taxation fraud and money laundering, the goods must either be non-dutiable ${ }^{48}$ or the importing country must have a weak customs framework $^{49}$ in order for the transaction to go completely unscrutinised by authorities. This often means that under-invoicing is at its most effective when used to transfer capital from jurisdictions with strict border and custom controls to jurisdictions that lack them.

\section{B Falsely or Inaccurately Described Goods or Services}

Volume-based methods rely on misrepresenting the quality or quantity of the goods or services subject to the transaction. In such a transaction, while the price stated closely corresponds with the market price of the goods or services declared, the underlying shipment does not match the declaration. This misrepresentation means that the transaction is under- or over-priced relative to the value of the goods or services that are actually shipped. Thus, the effect is broadly equivalent to under-invoicing and over-invoicing respectively.

For example, a party might falsify the quantity of goods shipped and thereby transfer more or less value than that stated on the commercial invoice. Similarly, no goods or services might be shipped (so-called 'phantom shipments ${ }^{50}$ ), with the parties simply creating fake invoices. Likewise, a party might misrepresent the type or quality of goods shipped or services provided in such a way as to misrepresent their value. While brazen cases of trading in falsely described goods involve making declarations that are patently false, ${ }^{51}$ more sophisticated launderers will provide general or imprecise declarations. If detected, such offenders can plausibly claim that the description, while careless, is not obviously criminal.

In any case, to detect transactions where goods or services have been falsely described, a physical inspection is usually required. This means that such

\footnotetext{
${ }^{47}$ Trade Based Money Laundering, above n 8, 5.

${ }^{48}$ Ibid.

${ }^{49}$ Ibid.

${ }^{50}$ Ibid 6.

${ }^{51}$ The FATF reports a case where a TBML/TF syndicate falsely reported to Canadian customs that a shipment of scrap metal weighed several hundred tonnes. The syndicate was exposed when officials noticed that the hull of the ship was well above the water line. See ibid 10.
} 
transactions are difficult for authorities to detect cost effectively. This is particularly so in the case of services or intangible property where the subject of the transaction may not be observable and/or assessable ex post without significant investigation. ${ }^{52}$

\section{THE RESPONSE OF LAW ENFORCEMENT}

The use of the trade system to unlawfully transfer capital between jurisdictions was identified and documented in the literature decades ago. ${ }^{53}$ Given this, it is somewhat surprising that TBML/FT 'has received relatively little attention from policy makers to date'. ${ }^{54}$ A possible explanation for this, discussed later in this paper, is that little reliable data exists on the scale of the problem. With counter-TBML/TF efforts likely to be costly, the lack of data makes the case for increased law enforcement resources difficult to make. That said, TBML/TF is increasingly treated as the 'next front' in AML/CTF efforts by international compliance organisations. ${ }^{55}$

There have been a number of efforts in this regard in recent years. Most notably, the Financial Action Task Force released a typologies report on TBML/TF in 2006, ${ }^{56}$ which was followed up in June 2008 with a best practices paper. $^{57}$ As yet there is, however, no specific FATF Recommendation on TBML/TF. Indeed, there are legitimate questions about whether the FATF's mandate extends to the trade system and whether it is the best forum to propagate reform, given the existence of international organisations devoted specifically to trade security and border control. It may be, for instance, that the FATF's financial sector expertise is of little practical benefit in the trade sector. In the Asia-Pacific, the Asia/Pacific Group on Money Laundering described TBML/TF in the 2004-05 typologies report ${ }^{58}$

\footnotetext{
${ }^{52}$ Ibid 6.

53 Jagdish Bhagwati, 'On the Underinvoicing of Imports' (1964) 26(4) Bulletin of the Oxford University Institute of Economics and Statistics 389 ('On the Underinvoicing of Imports'); Jagdish Bhagwati, 'Fiscal Policy: The Faking of Foreign Trade Declarations and the Balance of Payments' (1967) 29(1) Bulletin of the Oxford University Institute of Economics and Statistics 61.

${ }^{54}$ Financial Action Task Force, Best Practices Paper on Trade Based Money Laundering (Report, Organisation for Economic Co-operation and Development, 20 June 2008) 5 ('Best Practices Paper on Trade Based Money Laundering').

${ }^{55}$ Delston and Walls, above n 7, 117.

${ }^{56}$ Trade Based Money Laundering, above n 8.

${ }^{57}$ Best Practices Paper on Trade Based Money Laundering, above n 54.

${ }^{58}$ APG Typologies Working Group, APG Yearly Typologies Report 2004-05 ('Typologies Report, Asia/Pacific Group on Money Laundering, June 2005’) 8.
} 
and has continued to expend significant time on the issue in workshops. ${ }^{59}$ Both the Egmont Group ${ }^{60}$ and the Wolfsberg Group ${ }^{61}$ have acknowledged the TBML/TF problem. Again, however, given their preponderant focus on the financial sector, it is questionable whether these organisations are well placed to pursue a TBML/TF agenda. There is also, conceivably, a question about whether the expertise of these organisations extends to perennially delicate trade negotiations.

Perhaps unsurprisingly, given the pedigree of the AML/CTF regulators, much of the aforementioned policymaking seems to be preoccupied with adapting AML/CTF regulation from the financial sector and applying it to the trade sector. $^{62}$ The FATF, for example, advocates imposing reporting requirements, much like those that apply to the financial sector, on the trade sector and on traders in particular. Similarly, many, including the FATF, advocate AML/CTF auditing for traders. There are, of course, very real reasons to apply AML/CTF regulation to traders themselves rather than to financial intermediaries. ${ }^{63}$ Financial institutions are not well positioned to detect and report TBML/TF, given that, for 80 per cent of trade transactions, they provide no direct finance and are only able to see 'clean payments'. ${ }^{64}$ There are equally good reasons to learn from decades of AML/CTF experience in the financial sector. That said, there has been little attention given to the ways in which a regulatory regime might be tailored to the specific requirements of the freight sector.

Without detailed analysis of the sector, there is a clear and present risk that any TBML/TF regulation could prove costly and/or ineffective. For example, common proposals for reform include the expansion of customer identification requirements to traders $^{65}$ and the improvement of trade documentation. ${ }^{66}$ However, because agency shipping is ubiquitous,

59 Asia/Pacific Group on Money Laundering, Annual Report 1 July 2005 - 30 June 2006 ('Annual Report, Asia/Pacific Group on Money Laundering, March 2008') 12; Asia/Pacific Group on Money Laundering, The Asia/Pacific Group on Money Laundering Information Quarterly ('Quarterly Newsletter, Asia/Pacific Group on Money Laundering, November 2005') 1-2.

${ }^{60}$ The Egmont Group of Financial Intelligence Units, Annual Report July 2008 - June 2009 ('Report, The Egmont Group, July 2008 - June 2009') 6.

61 The Wolfsberg Group, The Wolfsberg Trade Finance Principles (2009) $<$ http://www.wolfsberg-principles.com/pdf/WG_Trade_Finance_Principles_Final_(Jan_09). pdf $\geq$.

${ }^{62}$ Best Practices Paper on Trade Based Money Laundering, above n 54, 2-4.

${ }^{63}$ Delston and Walls, above n 7, 117.

${ }^{64}$ The Wolfsberg Group, above n 61, 1.

${ }^{65}$ Delston and Walls, above n 7, 117.

${ }^{66}$ Passas, above n 24, 85; Nilson, above n 25, 311-12. 
identification requirements will need to be onerous indeed to discover beneficial ownership. Likewise, while the idea of improving documentation is laudable, trade documentation covers trillions of dollars worth of multifarious and heterogeneous trade transactions. Exactly how it might be improved and at what cost, is yet to be specified. Indeed, simplification of trade documentation has been a goal of trade reformers for at least four decades. ${ }^{67}$ It is improbable that the TBML/TF threat will motivate jurisdictions to resolve the intractable problems encountered thus far in long-running negotiations over trade documentation. Other regulations of questionable cost effectiveness include the designation of an AML/CTF compliance officer within traders; ongoing training of personnel; AML/CTF auditing and other remedies imported from the financial sector. ${ }^{68}$ This is because many traders lack the pre-existing compliance culture and expertise that exists within financial institutions and will have to develop such systems from scratch.

Most controversially, given the potential cost, is the imposition of suspicious transaction reporting obligations on traders. ${ }^{69}$ This obligation, whilst unlikely to impose actual investigative responsibility on traders, would be guided by red-flag indicators, much as it is in the financial sector. Delston has listed many of these indicators, including shipments to or from high-risk countries; apparently uncommercial transactions; the transport of items unrelated to a trader's business; frequent amendments to trade documentation; the involvement of third parties and/or shell companies; and carousel transactions (the importing and exporting of the same commodity). ${ }^{70}$

While there is little in-principle objection to such an arrangement (though privacy concerns are likely to be acute), there is significant doubt about the effectiveness of a reporting framework in the trade sector. Given the current industry structure, any given consignment is likely to pass through 'many hands'. Few of these companies - given a lack of direct contact with either the goods or the customer or both - will be in a position to detect suspicious transactions on the information available to them. Indeed, it is unlikely that any firm would be in a position to observe a transaction in its entirety, and thus be in a position to meaningfully comply with a reporting obligation.

Consider, for example, that a groupage shipment might originate at a UK business, be consolidated by a groupage company, be bailed to a consolidator, be shipped by a shipping agent, transit through Singapore and so on. Given this complexity, it is currently unclear upon whom a reporting obligation

\footnotetext{
${ }^{67}$ Simplification of Trade Documentation, UN Doc TN/TF/13, 1.

${ }^{68}$ Delston and Walls, above n 7, 117.

${ }^{69}$ Ibid.

${ }^{70}$ Trade Based Money Laundering, above n 8, 24; Delston and Walls, above n 7, 104-6.
} 
would fall and what level of customer and documentary diligence would be expected of them. Given the limited ability of trading companies to monitor shipments in their entirety, even an oppressive obligation could prove ineffective. Indeed, perhaps in recognition of this latter fact, advocates for suspicious trade transaction reporting often also advocate increased public resources for physical inspection and intelligence-based operations. ${ }^{71}$ Whether or not such increases eventuate, and what the division of responsibility between private and public enforcement would ideally be, is unknown.

\section{A The US Government's Response to TBML/TF}

Despite an increased level of awareness of TBML/TF and trade security generally, actual institutional or regulatory change at the national level is something of a rarity. ${ }^{72}$ The United States is the notable exception. In 2003, the US Bureau of International Narcotics and Law Enforcement Affairs first described TBML/TF as a distinct typology. ${ }^{73}$ By 2007, TBML/TF had been identified as a "priority threat" ${ }^{, 74}$ and the government was acknowledging that trade-based remittance systems were 'entrenched'. ${ }^{75}$ Considerable resources are now devoted to the TBML/TF threat by US authorities.

The most notable policy response was the formation of Trade Transparency Units ('TTUs') within Immigration and Customs Enforcement ('ICE'). The first TTU was created in 2004 to 'collect and analyze suspect trade data and then disseminate findings for appropriate enforcement action' ${ }^{76}$ The collection of such data was not, in itself, a new development. However, while ICE had always been able to monitor trade prices, it did not have a TBML/TF focus or appropriate enforcement tools. ${ }^{77}$ Moreover, its systems only recorded data submitted to US authorities. By contrast, the TTUs are designed as specialist TBML/TF investigators. Moreover, they are able to detect discrepancies between the documentation lodged with foreign authorities and

\footnotetext{
${ }^{71}$ Best Practices Paper on Trade Based Money Laundering, above n 54, [11]-[13], [20], [33](e).

${ }^{72}$ Delston and Walls, above n 7, 87-9, 99.

${ }^{73}$ International Narcotics Control, above n 14, 5.

${ }^{74}$ Ibid.

${ }^{75}$ Bureau for International Narcotics and Law Enforcement Affairs, US Department of State, Trade Transparency Units: International Narcotics Control Strategy Report: Volume II Money laundering and Financial Crimes (March 2005), <http://www.state.gov/p/ inl/rls/nrcrpt/2005/vol2/html/42381.htm> ('Trade Transparency Units').

${ }^{76}$ Ibid.

${ }^{77}$ Ibid.
} 
the documentation lodged locally. ${ }^{78}$ This is described publicly in the following terms:

At the core of the TTU concept is the Data Analysis \& Research for Trade Transparency System (DARTTS), an ICE computer system designed to analyze import/export and financial data of the United States and its foreign partners for the purpose of identifying trade anomalies and financial irregularities. These anomalies and irregularities often serve as indicators of money laundering, customs fraud, contraband smuggling, and even tax evasion (e.g. value added tax, income tax, duty, tariff). ${ }^{79}$

To obtain such data, the US government has begun sponsoring a 'worldwide TTU network somewhat analogous to the Egmont Group of Financial Intelligence Units ('FIUs'). ${ }^{80}$ Foreign TTUs have now been established in Argentina, Brazil, Paraguay, Mexico and Columbia. ${ }^{81}$ In 2010, Panama will become the sixth country to host a US-sponsored TTU. ${ }^{82}$ The focus on Latin America reflects longstanding intelligence that drug producers are using TBML/TF to transfer revenue out of the United States. The US government has also approached Eastern and Central European countries about establishing local TTUs, ${ }^{83}$ but this is yet to produce results. ${ }^{84}$ While the aspiration of the US government is for a global network of TTUs, the current network is limited.

\section{B Current Analytical Techniques for TBML/TF Detection}

As far as can be ascertained from public information, the US government's TTUs are utilising two different TBML/TF detection techniques. These can be roughly described as unit price analysis and bilateral trade price analysis. Both

\footnotetext{
${ }^{78}$ Ibid.

${ }^{79}$ Office of Investigations, Topics of Interest: Trade-Based Money Laundering (26 March 2009), US Immigration and Customs Enforcement <http://www.ice.gov/partners/financial/ topics.htm>.

80 Trade Transparency Unit, above n 75. A financial intelligence unit is a specialist investigative body that systematically monitors the financial and banking system for law enforcement (including, usually, tax compliance) purposes. The Australian FIU is the Australian Transaction Reports and Analysis Centre ('AUSTRAC').

${ }^{81}$ US Immigration and Customs Enforcement, 'ICE launches Trade Transparency Unit in Mexico City as Part of Bi-Lateral Cooperation with Mexico Customs' (Media Release, 12 June 2008) <http://www.ice.gov/pi/news/newsreleases/articles/080612mexicocity.htm>.

${ }^{82}$ Bureau for International Narcotics and Law Enforcement Affairs, United States Department of State, International Narcotics Control Strategy Report: Vol II - Money laundering and Financial Crimes (2010) 11.

${ }^{83}$ Trade Transparency Units, above n 75.

${ }^{84}$ International Narcotics Control, above n 14, 18.
} 
techniques use existing customs data and do not require radical changes to trade regulation. ${ }^{85}$ Both are endorsed by the FATF. ${ }^{86}$ However, neither technique is generally effective at detecting volume-based typologies; these require physical inspection and/or intelligence-based investigation to detect. ${ }^{87}$ That said, to the extent that the data mining techniques reveal suspicious transactions and/or traders, this can inform the investigation of volume-based typologies.

Pak et al are often credited with giving the first exposition of unit price analysis. ${ }^{88}$ Requiring highly disaggregated trade data, unit price analysis classifies individual transactions into a harmonised system of goods classification, for example textiles, resources, foodstuffs. As the name suggests, the methodology calculates a 'per unit' price (usually an average, or weighted average, price) to detect abnormal trade pricing. By averaging prices across highly specific product categories, unit price analysis identifies as suspicious those transactions that deviate from a mean and/or median. Clearly, for this to be effective, heterogeneity within each product category must be minimised in order to cluster the prices closely. ${ }^{89}$ While this is unlikely to be problematic in exchange-traded homogeneous commodities, it is likely to be enormously difficult in most other product categories.

The second technique - bilateral trade price analysis - is much older. It was developed prior to the widespread use of harmonised trade codes, when only highly aggregated trade data was available. The existence of harmonised trade codes has made the technique more effective, but the methodology is still the same. The basic reference remains Bhagwati. ${ }^{90}$ The simple premise of the analysis is that imports in any one country must originate as exports in another. Hence, the ratio of imports from one country to exports from another ought to equal one. ${ }^{91}$ Once legitimate explanations for a discrepancy are excluded, a ratio that does not equal one indicates valuation discrepancies and abnormal trade prices.

85 Trade Transparency Units, above n 75; K Kibble, 'Countering Trans-border Threats', Immigration and Customs Enforcement, Conference Presentation, (Seattle, 15 April 2008).

${ }^{86}$ Best Practices Paper on Trade Based Money Laundering, above n 54, $2-4$.

${ }^{87}$ Trade Based Money Laundering, above n 8, 5.

${ }^{88} \mathrm{~S}$ Pak and J Zdanowicz, 'The statistical analysis of the U.S. merchandise trade database and its uses in transfer pricing compliance and enforcement' (1994) 3(1) Tax Management 50; Pak, Zanakis and Zdanowicz, above n 2; John Zdanowicz, Simon Pak and Michael Sullivan 'Brazil-United States Trade: Capital Flight Through Abnormal Pricing' (1999) 13(4) The International Trade Journal 423.

${ }^{89}$ Zdanowicz, Pak and Sullivan, above n 88, 432.

${ }^{90}$ Bhagwati, 'On the Underinvoicing of Imports', above n 53.

${ }^{91}$ Luc de Wulf, 'Statistical Analysis of Under- and OverInvoicing of Imports' (1981) 8 Journal of Development Economics 303, 304. 
Both techniques are limited by poor data quality. In international trade, erroneous assignments of origin or destination are extremely common. ${ }^{92}$ This is particularly true when the shipment passes through global transit ports, for example Singapore, ${ }^{93}$ or the exporter/importer is not actually located in the origin/destination country. ${ }^{94}$ Classification errors occur either accidentally (because there are a very large number of classifications many shippers use the wrong code or use the general codes) or for illicit purposes (for example, evading quotas, avoiding tax). ${ }^{95}$ Further, it is difficult to exclude the possibility that a shipment has changed en-route; for example, the value or exchange rate might change. ${ }^{96}$ Lastly, a customs valuation/declaration does not always mimic the invoice, ${ }^{97}$ often for legitimate commercial reasons (for example, because of credit for previous purchases, shipping costs and so forth). This is problematic, as money launderers often make multiple, obfuscatory changes to documentation. ${ }^{98}$

A particular difficulty of bilateral analysis is attempting to exclude legitimate explanations for valuation discrepancies. Between two countries, there might be a valuation bias (either generally or with respect to the trade relationship) or currency fluctuations. ${ }^{99}$ Major differences exist in customs import valuation methodologies ${ }^{100}$ and customs administrative fees (which are often built into the import price). ${ }^{101}$ For example, in a bilateral transaction, imports are valued on a c.i.f. basis, ${ }^{102}$ whereas exports are valued on an f.o.b. basis. ${ }^{103}$ The difference is the freight and insurance cost; however, these costs are heterogeneous and therefore difficult to account for systematically. Nevertheless, they must be accounted for, as indeed must the possibility that the valuation has changed while goods are in transit, ${ }^{104}$ or the trading parties have failed to hedge against exchange rate movements. Lastly, accurate records actually need to exist in both countries, which is unlikely to be the case with shipments originating from or transiting through developing or noncompliant economies.

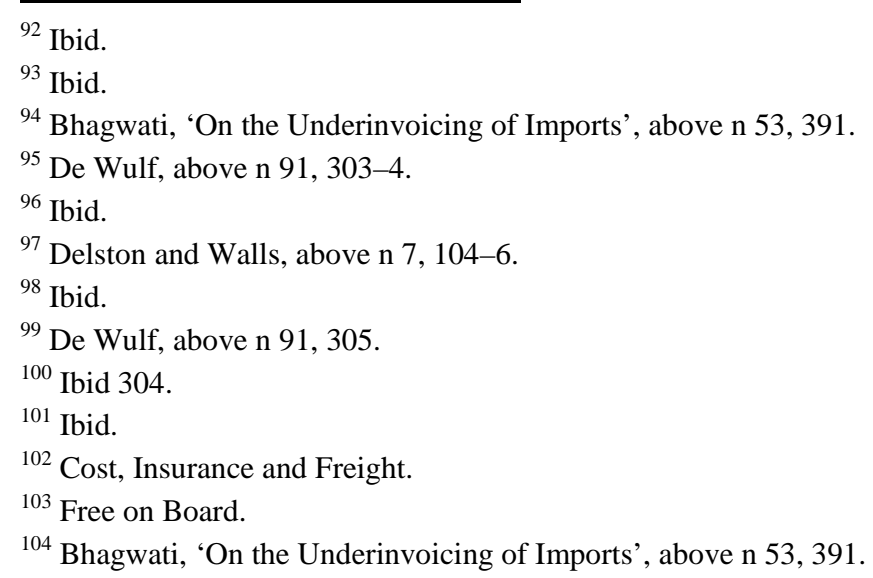


While unit price analysis avoids the problems of obtaining comparable trade data, it has its own problems. First, it is only effective when goods are homogeneously and consistently valued (for example commodities). ${ }^{105}$ When this is not the case, then unit price analysis is ineffective because a robust mean for the goods cannot be calculated. Consider for example, the problem of shippers labelling goods as 'textiles' or 'gifts' - categories that are obviously far too broad to justify the key assumption that the average price approximates the market price. Second, a fundamental weakness is that unit price analysis depends on the existence of a benchmark against which 'abnormality' can be assessed. This benchmark is normally set at an outer quartile (that is, a substantial deviation from the mean). ${ }^{106} \mathrm{~A}$ lower benchmark would, in most product categories, produce considerably more false positives. While such analysis is effective at catching tax fraud (as tax minimisation relies on a large difference between price and value), the inherent flaw from a capital transfer perspective is that reducing the price discrepancy while increasing volume can circumvent detection techniques but not reduce the utility of the transaction to the launderer. ${ }^{107}$

\section{The Threat Posed by TBML/TFT Typologies}

A comprehensive response to the TBML/TF threat will require expansive regulation of the international shipping and transport sector. ${ }^{108}$ Given the cost of such regulation, it is prudent to proportion the remedy relative to the threat posed by TBML/TF. However, there is little data available on the significance of TBML/TF's effects and even less on the cost of proposed responses. While measures such as TTUs have a certain initial appeal, there is a question about whether they are a value for money proposition relative to the threat posed by TBML/TF.

\footnotetext{
${ }^{105}$ De Boyrie, Pak and Zdanowicz, Money Laundering and Income Tax Evasion, above n 4, 126-7.

${ }^{106}$ Ibid.

${ }^{107}$ For example, \$1 000000 can be laundered by under-invoicing 125000 widgets valued at $\$ 10$ for \$2 (an \$8 discount). Alternatively, the launderer can send 1000000 widgets priced at $\$ 9$ (a $\$ 1$ discount). In the latter example, such a small departure from the mean unit price would likely go undetected, whereas the large difference in the former example would be detected. Either way, the launderer has transferred the same amount.

By contrast, if the offender were seeking to minimise their tax, this strategy would be ineffective. Assume, for example, that the import duty was five per cent of the value declared to customs. In the first case, tax levied would be $\$ 12500$, while in the second it would be $\$ 450$ 000. In the latter case, tax would be only slightly minimised relative to the actual liability (\$500 000).

108 Delston and Walls, above n 7, 106-10; Best Practices Paper on Trade Based Money Laundering, above n 54.
} 
The cost effectiveness of AML/CTF regulation is an issue of general importance, extending well beyond the trade sector. Unfortunately, the evidence that is available is neither transparent nor, many claim, particularly reliable. Brigitte Unger et al have described the 'evidence' on money laundering's effects as being “"black box” ... estimates [that] arbitrarily circulate like magic figures throughout the world'. ${ }^{109}$ These estimates, which 'international organizations refer to ... constantly', ${ }^{110}$ are rightly and appropriately criticised for not being reproducible, transparent or scientific. ${ }^{111}$ The global organisations that cite them 'reveal a disturbing tendency to quote each other's work; since they enjoy substantially the same membership, this practice amounts to self-corroboration'. ${ }^{112}$ Without significant countervailing engagement with these organisations, ${ }^{113}$ much of the literature is anecdotal in nature:

Most literature on money laundering effects is pure speculation. ... [It uses] sentences such as 'it is clear from available evidence' that money laundering has such and such effects, without ever giving a hint where this evidence should be. ${ }^{114}$

Of course, part of the broader problem is one of data availability. There is little reliable data on the volume of capital that is laundered, ${ }^{115}$ which of course, makes estimating its effects almost impossible. Within this context, it is not possible to convincingly demonstrate the effects of money laundering generally, let alone the particular effect of TBML/TF. This, in turn, makes responding proportionally to the TBML/TF threat very difficult.

${ }^{109}$ Brigitte Unger et al, The Amounts and the Effects of Money Laundering (Report for the Ministry of Finance (Netherlands), 16 February 2006) 3.

${ }^{110}$ Ibid.

${ }^{111}$ Ibid 38; Donato Masciandaro and Raffaella Barone 'Worldwide Anti-Money Laundering Regulation: Estimating Costs and Benefits' (2008) 10(3) Global Business and Economics Review 243, 253; F Schneider, 'Money laundering and financial means of organised crime: some preliminary empirical findings' (2008) 10(3) Global Business and Economics Review 309, 323.

112 Nigel Morris-Cotterill, ‘Think Again: Money Laundering' Foreign Policy [2001] (May/June) 22, quoted in Unger et al, above n 109, 2.

113 John Broome, Anti Money laundering: International Practice and Policies (Thomson, 2006), 562-3.

${ }^{114}$ Unger et al, above n 109, 102.

115 Alberto Chong and Florencio López-De-Silanes, 'Money Laundering and its Regulation' (Working Paper No 590, Inter-American Development Bank, 2007), 8; F Schneider, 'Money laundering and financial means of organised crime: some preliminary empirical findings' (2008) 10(3) Global Business and Economics Review 309, 312; D Masciandaro et al. 'Worldwide Anti-Money Laundering Regulation: Estimating Costs and Benefits' (2008) 10(3) Global Business and Economics Review 243, 252 ('Worldwide Anti-Money Laundering'). 


\section{A Economic Effects and the Capital Flight Context}

That said, TBML/TF is, in some respects, little more than a particular subset of a much larger phenomenon: capital flight motivated by rational, wealthmaximising economic behaviour. ${ }^{116}$ There is a very large volume of international capital that flows out of countries for rational risk aversion reasons. Such reasons include the threat of expropriation, ${ }^{117}$ fiscal deficits, ${ }^{118}$ currency devaluation, ${ }^{119}$ economic uncertainty and political risk and insecurity. ${ }^{120}$ According to Maria de Boyrie, Simon Pak and Peter Zdanowicz such flows can 'erode a country's tax base, increase public deficit, reduce domestic investment and destabilize financial markets'. ${ }^{121}$ Recognising this, countries at risk of capital flight impose tight foreign exchange controls as a means of retaining national wealth. These controls are commonly avoided by use of the trade system, with the literature documenting trade-based capital transfers since at least the post-war years, if not earlier. ${ }^{122}$

The volume of illegal capital exports in the trade system is significant. Peter Zdanowicz, Simon Pak and Michael Sullivan estimate that, in 1995, capital flight from Brazil into the United States in the trade system amounted to between US\$2 and US\$4 billion. ${ }^{123}$ In another study, Simon Pak, Stelios Zanakis and Peter Zdanowicz used the same framework to estimate that, in 1995, trade mispricing exported around US\$5.5 billion of capital from Greece - or four per cent of gross domestic product. ${ }^{124}$ De Boyrie, Pak and Zdanowicz also estimate that, between 1995 and 2000, US\$31 billion was

\footnotetext{
116 De Boyrie, Pak and Zdanowicz, The Impact of Switzerland's Money Laundering Laws, above n 9, 4; Ila Patnaik and Deepa Vasudevan 'Trade Misinvoicing and Capital Flight from India’ (2000) 14 Journal of International Economic Studies 99.

${ }^{117}$ Mohsin S Khan and Nadeem Ul Haque, 'Foreign Borrowing and Capital Flight: A Formal Analysis’ (1985) 32(4) Staff Papers: International Monetary Fund 606, 608.

118 John T Cuddington, 'Capital Flight' (1987) 31 European Economic Review 382, 388; De Boyrie, Pak and Zdanowicz. The Impact of Switzerland’s Money Laundering, above n 9, 5.

119 Myrvin L Anthony and Andrew J Hughes Hallett, 'How Successfully Do We Measure Capital Flight? The Empirical Evidence from Five Developing Countries’ (1992) 28(3) Journal of Development Studies 538.

${ }^{120}$ Michael P Dooley and Peter Isard, 'Capital Controls, Political Risk, and Deviations from Interest-Rate Parity’ (1980) 88(2) Journal of Political Economy 370, 382.

${ }^{121}$ Marie E de Boyrie, Simon J Pak, John S Zdanowicz, 'Estimating the Magnitude of Capital Flight Due to Abnormal Pricing in International Trade: The Russia-USA Case’ (Working Paper, Centre for International Business and Education Research, Florida International University, 2005) 5 ('Estimating the Magnitude of Capital Flight').

${ }^{122}$ De Boyrie, Pak and Zdanowicz, The Impact of Switzerland's Money Laundering Law, above n 9, 4.

${ }^{123}$ Zdanowicz, Pak and Sullivan, above n 88, 424.

${ }^{124}$ Pak, Zanakis and Zdanowicz, above n 2, 54, 59.
} 
unlawfully exported from Switzerland to the US through the trade system. ${ }^{125}$ On a monthly basis, this amounts to between 10 per cent and 50 per cent of total trade volume. ${ }^{126}$ In countries with very high sovereign risk, the estimates become astronomical. The Russian government estimates that up to US\$400 billion was exported unlawfully during post-Soviet transition, an estimate thought by some academics to be much lower than the true figure. ${ }^{127}$

Making an empirical distinction between capital flight and TBML/TF is difficult, as both are subject to substantial measurement problems, and are not, in any case, mutually exclusive. Thus, any economic observations about effects must be largely conceptual. A distinction between TBML/TF and capital flight is exemplified by the fact that the latter, while a problem for many countries, is not itself usually distortionary. It is rational to diversify away from areas of abnormally high systemic or sovereign risk. In this sense, the capital flows observed from high-risk countries are not themselves distortionary but rather symptoms of distortion. ${ }^{128}$ TBML/TF on the other hand, is unambiguously distortionary. In general terms, money laundering distorts consumption ${ }^{129}$ and investment, ${ }^{130}$ by allocating capital on grounds other than wealth-maximisation, that is, on the value derived from obscuring the money, rather than economic utility. Further, money laundering redirects capital from high-savers to low-savers, ${ }^{131}$ the capital then being consumed in a less than optimal way. Of course, whether or not such an effect is significant or merely theoretical is largely unknown.

A particular effect of TBML/TF (and indeed capital flight) is the scope for import/export prices to be inefficiently determined. An excess of supply or a depressed import price could depress local prices through dumping, ${ }^{132}$

\footnotetext{
${ }^{125}$ De Boyrie, Pak and Zdanowicz, The Impact of Switzerland's Money Laundering Law, above n 9, 19.

${ }^{126}$ Ibid.

${ }^{127}$ De Boyrie, Pak and Zdanowicz, Estimating Magnitude of Capital Flight, above n 121, 6.

${ }^{128}$ Darryl McLeod, 'Capital Flight' in Daniel Henderson (ed), The Fortune Encyclopaedia of Economics (Warner Books, 1993) 723, 723-6.

${ }^{129}$ John Walker, 'Estimates of the Extent of Money Laundering In and Through Australia' (Paper prepared for Australian Transaction Reports and Analysis Centre, September 1995) 30; Brent L Bartlett 'The Negative Effects of Money Laundering on Economic Development' (2002) 77 Platypus Magazine, 19, cited in Unger et al, above n 109, 84.

${ }^{130}$ Peter J Quirk, Macroeconomic Implications of Money Laundering (Working Paper No 96/66, International Monetary Fund, 1996) ('Macroeconomic Implications'); Vito Tanzi, Money Laundering and the International Financial System (Working Paper No 96/55, International Monetary Fund, 1996).

${ }^{131}$ Unger et al, above n 109, 85.

${ }^{132}$ De Boyrie, Nelson and Pak, 'Capital Movement through Trade Misinvoicing', above n 5, 475.
} 
whereas a lack of supply or an excessive import price could (in the absence of effective competition ${ }^{133}$ ) exacerbate supra-competitive pricing. This effect might be exacerbated by the fact that money launderers do not seek out a competitive price - they both buy and sell goods with an endogenous valuation (the 'value' of the crime, rather than the product). Further, depending on the value of trade flows, TBML/TF could theoretically exacerbate a balance of payments problem. ${ }^{134}$ There is some scope for TBML/TF to destabilise global capital because movements would not reflect differences in economic fundamentals across countries. ${ }^{135}$ It is worth noting, however, that in the countries most at risk of such volatility (for example, those with comparatively illiquid currencies), the likelihood of economic and political instability may also be distorting currency markets.

An additional issue is that TBML/TF will direct capital away from countries with rigorous border procedures, and into those jurisdictions with no import controls. ${ }^{136}$ While this may mean that trade goods are directed suboptimally, ${ }^{137}$ the need for resale markets - together with the fact that trade monitoring is almost uniformly inadequate - tempers this effect.

As noted earlier, whether or not these observations are empirically significant is largely unknown. Both Vito Tanzi ${ }^{138}$ and Peter Quirk ${ }^{139}$ attempted to use cash-in-circulation data to measure foreign exchange instability caused by money laundering. Further, Quick has attempted to find a correlation between gross domestic product and a growth in the money laundering rate. ${ }^{140}$ These papers are useful, but their high level of macroeconomic abstraction does not assist in identifying the specific effects of TBML/TF. Walker has attempted to use input/output analysis to show the employment and consumption effect of money laundering, though his analysis is of little application in the TBML/TF context. ${ }^{141}$ The Walker model assumes a closed economy, with the proceeds

\footnotetext{
${ }^{133}$ Walker, above n 129, 33; Douglas I Keh, 'Economic Reform and Criminal Finance’ (1996) 2(1) Transnational Organized Crime 66, 5, cited in Unger, above n 118, 86.

${ }^{134}$ Unger et al, above n 109, 86.

135 Tanzi, above n 130, 8; Unger et al, above n 109, 89.

136 Trade Based Money Laundering, above n 8, 5.

137 Tanzi, above n 130, 6.

138 Vito Tanzi 'Macroeconomic Implications of Money laundering' in Ernesto Ugo Savona (ed), Responding to Money Laundering, International Perspectives (Harwood Academic Publishers, 1997) 91, 91-104, cited in Unger et al, above n 109, 102.

139 Quirk, Macroeconomic Implications, above n 130; Peter J Quirk 'Money Laundering: Muddying the Macroeconomy’ [1997] (March) Finance \& Development, 7, 7-9.

${ }^{140}$ Quirk, Macroeconomic Implications, above n 130.

${ }^{141}$ Walker, above n 129.
} 
of crime domestically generated and laundered, ${ }^{142}$ an assumption with obvious problems in the TBML/TF context.

Given how little is known about the economic effects of TBML/TF, there are good reasons to be prudent in formulating a policy response. It is worth bearing in mind 'Lilley's Option', that is, the option to 'do nothing'. Lilley's Option was named after a former Conservative cabinet minister in the United Kingdom, who, as the story goes, insisted that maintaining the status quo be inserted into all policy recommendations. The intent was to remind policymakers of the need for proportionality in any response. In the present circumstances, in the absence of any reliable data on the scale of TBML/TF and the extent to which it is distorting otherwise well functioning markets, there is scope for the remedy to be worse than the disease. Increased TBML/TF regulation would increase the cost of international trade, with an obvious effect on prices. Further, it would act as a trade barrier - with consequently profound effects on domestic competitiveness and productivity. Given this, further research is needed before extensive new regulation is adopted.

\section{B The Crime Causation Thesis and the Social Effect of TBML/TF}

Putting aside these economic issues, it is worth noting that a large proportion of the money laundering literature is concerned with 'crime causation', that is, the idea that 'money laundering helps make crime worthwhile'. ${ }^{143}$ 'Crime', writes Peter Lilley, 'can only succeed if the funds generated can be utilized without their true source being known'. ${ }^{144}$ If the proceeds of crime are confiscated or are otherwise rendered valueless, then the purpose of much crime simply evaporates. This assumption underlies both AML/CTF laws and proceeds of crime legislation. Indeed, a multiplier allegedly exists whereby the proceeds of crime fund future criminal activity - thereby begetting more revenue and consequently more crime. ${ }^{145}$ Donato Masciandaro has empirically demonstrated that this multiplier can, theoretically, negate the

\footnotetext{
${ }^{142}$ Unger et al, above n 109, 105.

143 Neil Mackrell, 'Economic Consequences of Money Laundering' in Adam Graycar and Peter Grabosky (eds), Money Laundering in the $21^{\text {st }}$ Century: Risks and Countermeasures (Australian Institute of Criminology 1996) 3, quoted in Unger et al, above n 109, 83.

144 Peter Lilley, Dirty Dealing: The Untold Truth about Global Money Laundering, International Crime and Terrorism (Kogan Page, $3^{\text {rd }}$ ed, 2006) xi.

145 Ibid; Michael Levi, 'Money Laundering and its Regulation' (2002) 582 ANNALS of the American Academy of Political and Social Science 181, 182-3.
} 
benefits of enforcement. ${ }^{146}$ In any case, according to this thesis, if proceeds are confiscated and this multiplier reduced, then the future crime rate is improved.

So, simply put, deterring money laundering is equivalent to deterring crime the latter being, of course, undesirable from economic, ${ }^{147}$ social, and ethical standpoints. This simple logic obscures the essential empirical question of crime deterrence: are the actual or threatened prosecutions of an offence likely to deter its commission in the future? There is no clear or empirically sound consensus answer to this question. ${ }^{148}$ There is some research suggesting that the money laundering rate is insensitive to changes in the number of money laundering prosecutions conducted because the demand for it is linked to the predicate crime, and thus, as long as there is crime-for-profit, there will always be money laundering. ${ }^{149}$ Whether or not this is correct, it nevertheless invites a second, more difficult, question on whether the prosecution of money laundering offences can be empirically shown to deter the commission of predicate offences. ${ }^{150}$

It is well beyond the scope of this paper to attempt to answer this question. One expects that the answer must be no, as law enforcement cannot ever hope to prosecute enough AML/CTF offences to render crime unprofitable at anything other than the margins. Indeed, it is worth noting the improbability of increased TBML/TF prosecutions alone having a measurable effect on the entrenched international crime syndicates and terrorist networks that profit from it. As put by Előd Takáts, 'it is hard to imagine drug dealers stopping their illicit trade in response to money laundering prosecution alone'. ${ }^{151}$ For this reason, if no other, claims that extensive TBML/TF regulation of the trade system is needed to 'stop terrorists and drug dealers' should be treated with some scepticism.

146 Donato Masciandaro, 'Money Laundering: The Economics of Regulation' (1999) 7 European Journal of Law and Economics 225 ('The Economics of Regulation'); Masciandaro, 'Worldwide Anti-Money Laundering', above n 115, 243.

${ }^{147}$ Richard A Posner, 'An Economic Theory of the Criminal Law' (1985) 85(6) Columbia Law Review 1193.

${ }^{148}$ Ibid; A Hirsch, A Bottoms, E Burney and P Wikstrom, Criminal Deterrence and Sentence Severity: An Analysis of Recent Research (Hart Publishing, 1999); Daniel S Nagin, 'Criminal Deterrence Research at the Outset of the Twenty-First Century' (1998) 23 Crime and Justice 1; Gary S Becker, 'Crime and Punishment: An Economic Approach' (1968) 76(2) The Journal of Political Economy 169.

${ }^{149}$ Elöd Takáts, A Theory of 'Crying Wolf': The Economics of Money Laundering Enforcement (Working Paper No WP/07/81, International Monetary Fund, April 2007) 39.

${ }^{150}$ Masciandaro, 'The Economics of Regulation', above n 146; Masciandaro, 'Worldwide AntiMoney Laundering', above n 115.

${ }^{151}$ Takáts, above n 149, 39. 


\section{CONCLUding Remarks}

According to the FATF, '[i]nherent vulnerabilities in the international trade system ... provide abundant opportunity for criminal organisations and terrorist groups to transfer value across borders'. ${ }^{152}$ In many respects, this is all that is known about the TBML/TF problem - there is a 'chink in the armour' but we do not know how much it is utilised or even how to close it. There is an 'opportunity' to abuse the trade system but how much it is being exploited and how much it will cost to remove it are unknown factors. 'The bad guys know how open the system is' says Stephen Flynn. 'The good guys do not have a real command on it ... because we have not paid as much attention to this problem as we need to'. ${ }^{153}$

The absence of data on TBML/TF is particularly concerning in light of the fact that TBML/TF is a credible substitute for traditional, financial system money laundering typologies. If offenders are able to avoid the ambit of AML/CTF legislation by switching to the trade system in substantial numbers, then costly regulation of the financial sector loses much of its lustre. The fact that those most able to take advantage of TBML/TF are likely to be the larger, organised crime syndicates that the AML/CTF legislation sets out to detect makes this even more concerning.

Be that as it may, preventing TBML/TF will take more than importing AML/CTF strategies from the financial sector, which can be of questionable effectiveness even in their own context. Instead, a robust new approach to AML/CTF in the trade sector will be required. It is clear '[that] to be effective, it should encompass [traders]' ${ }^{154}$ Traders though, are not banks. By and large, they lack the sophisticated and entrenched institutional mechanisms for compliance that exist in financial institutions. They lack customer relationship management platforms; indeed, they often have little direct contact with customers at all. They are lightly regulated in many respects and are directed at a diverse range of industry sectors - from consumer transactions to bulk-material shipping. Given this, how authorities will regulate traders in order to monitor billions of transactions, encompassing millions of containers, in a cost-effective and efficient way is the great, uncontemplated challenge of TBML/TF enforcement.

\footnotetext{
${ }^{152}$ Best Practices Paper on Trade Based Money Laundering, above n 54, 1.

${ }^{153}$ Stephen Flynn, former National Guard Commander, quoted in Delston (2009), above n 7, 99.

${ }^{154}$ Delston and Walls, above n 7, 118.
} 